\title{
Freedom of the Media in Sri Lanka: A Study
}

\author{
S. Sribreindranis ${ }^{1}$ and P. Govinduraju ${ }^{2}$ \\ ${ }^{1}$ Research Scholar, ${ }^{2}$ Professor \\ Department of Communication, Manonmaniam Sundaranar University, Tirunelveli, Tamil Nadu, India \\ E-Mail: breindaranmedia@gmail.com,pgraju1961@gmail.com
}

\begin{abstract}
Media freedom has never been consistent in Sri Lanka. Different regimes used legal and constitutional means to control the media from public debates and criticisms. The Constitution of Sri Lanka does not specifically mention the freedom of the media. Freedom of the Media is implied from the Article 14(1) (a) of the Constitution. However this right is subject to restrictions under sub-clause, whereby this freedom can be restricted for reasons of sovereignty and integrity of Sri Lanka, the security of the Country, Parliamentary privileges, public order, Emergency Regulations, relation to contempt of court, defamation, or incitement to an offense and Official Secrets Acts. As per the Press Council, the freedom of the journalist is an ordinary part of the freedom of the subjects and to whatever length, the subject in general may go, so also may the journalist, but apart from statute this privilege is no other and no higher. The range of his assertions, his criticisms or his comments is as wide as and no wider than that of any other subject. The Preamble of the Sri Lankan Constitution ensures to all its citizens the liberty of expression. Freedom of the media has been included as part of freedom of speech and expression under the Article 14 of the UDHR. The heart of the Article14 says that everyone has the right to freedom of opinion and expression, this right includes freedom to hold opinions without interference and to seek, receive and impart information and ideas through any media and regardless of frontiers. In view of the above, Right of Information Act 2016 is a milestone in the guest for building an informed and prosperous society. As this overview of Sri Lankan media Laws show, their social media enjoy a wide range of legal rights. This study focuses on Judgments of the cases on Joseph Perera v Attorney General, Visuvalingam $v$ Liyanage and Fernando $v$ Sri Lanka Broadcasting Corporation were delivered under the 1972 Republican Constitution, they continued to remain valid precedents even under the Current Constitution of 1978. It was an Important and far - reaching Judgment. This paper is a critical analysis of the Sri Lankan concept of Freedom of the media and how it is related to the concept of expression in Constitution of Sri Lanka. The judicial view in this context has also been studied.
\end{abstract}

Keywords: Media freedom, Parliamentary privileges, Emergency Regulations, Right of Information Press Council, Defamation

\section{INTRODUCTION}

Freedom of theMedia is the foundation of democracy. Freedom of the media may be interpreted as the right to access Information held by public bodes or more broadly as including access to and circulation of Information held by other actors. It is intrinsically linked to the basichuman right of freedom of speech and Expression. (Norris, 2006).The existence of a free, independent and powerful media is the cornerstone of a democracy,country like Sri Lanka. It is not only a medium to express one's opinions andviews, but also it is an effective instrument for building opinions and views on various community, national and international issues. Thus the crucial role of the media is its ability tomobilize the thinking process of millions. It is the mean by which people receive free flowof information and ideas, which is essential for an intelligent self-governance, that is, democracy. Besides the media plays an important role in not only mobilizing public opinion but alsobringing to light injustices which would have most likely gone unnoticed. A free media standsas one of the greatest tointerpreters between the government and the people. The strength andimportance of media in democracy is well recognized. The framers of the Constitutionprovided the press with broad freedom. This freedom was considered necessary to the establishment of a strong, independent media sometimes referred to as the "Fourth Estate".An independent media can provide citizens with a variety of information and opinions onmatters of public importance. The nation of freedom of Information or media was recognized by the united nation as early as in 1946 (un declaration) and has been long enshrined as part of the basic human right of freedom of expression in major international instruments like the universal Declaration of Human right (1948)Literally 'freedom' means absence of control, interference or restrictions. (Universal Declaration. 1948) Hence, theexpression 'freedom of media' means the right to print and publish without any interferencefrom the state or any other public authority. In other words, freedom of the press or freedom of the media is the freedom of communication and expression through mediums includingvarious electronic media and published materials. While such freedom mostly implies theabsence of interference from an overreaching state, its preservation may be sought throughconstitutional or other legal protections. Freedom of press applies to all types of printedand broadcast material, including books, newspapers, magazines, pamphlets, films and radio, televisionPrograms and News. Freedom of the media in the Sri Lanka ismore than a legal concept - it is almost a religious tenet. The Constitution, as interpreted by the Supreme Court of the Sri Lanka, is itself virtually a sacred text

\section{CONSTITUTIONAL MANDATE}

The Sri Lankan media has a long history right from the times ofBritish rule in the country. The first curbs of 
freedom of media in Sri Lanka, then known as Ceylon, came into effect the island-nation.The British Government passed anumber of legislations to regulate the activities of the media, Although the colonial rulers did not see any reason to enforce media curb in Sri Lanka at the time, the laws enacted to control the vibrant Bengali publications in India became applicable to Ceylon as the viceroy in Calcutta had ruled the subcontinent, which comprises India, Pakistan ,Bangladesh ,Burma and Sri Lanka as a single unit (Senadhira,S,P.,1996). After the sealing of the Independent media wielded a very Influential position in power politics in Sri Lanka.Thereforduring the framing of Sri Lankan Constitution after independencies the Constituent Assembly, the founding fathers gave emphasis on the Freedom of media. But surprisingly freedomofmedia was not specifically incorporated in the list ofFundamental Rights in the Constitution.

Apart from the relevant clauses in the constitution on the press and audio-visual media, a separate body - Sri Lanka press Council- was set up in 1973 to govern the media. Among its main objectives were to ensure freedom of the media, set high standards of journalistic ethics and the providing of research and training facilities for journalists. Under the Sri Lanka press Council Bill of 1973, the appointing authority of the press Council was the president. It was described as a regulatory body with semi- official powers constituted with the aim of encouraging free speech and expression.

Under the press Council Law there was a censorship on certain types of publication, including reports on government decision - making, fiscal policy, official secrets and defamation. These powers gave an authoritarian role to the press council as it could take punitive action against any journalist for publishing reports on government policies based on reliable information or 'leaks' obtained from official sources.As news journalism is largely dependent on official sources which cannot be named for obvious reasons the powers vested with the press Council resulted in curtailing media freedom instead of strengthening it, as stated by Press Council Bill.(Press Council,1973).

Freedom of expressionsguaranteed by Article 14 of chapter 3 0n fundamental Rights inthe1978 constitution. This Article guarantees every citizen freedom of expression, including publication. It also protects the rights to freedom of assembly, association, occupation and movement. ${ }^{7}$ However, the right to receive information is not expressly included in the constitution of 1978The freedom of expression is, however, subject to certain possible restrictions in article 15 of chapter 3 which sets forth the circumstances under which fundamental right may be restricted. It says that the exercise and operation of the fundamental right to freedom of expressionshall be subject to such restrictions as may be prescribed by law in the interests to such restrictions as may be prescribed by law in the interests of racial or religious harmony or in relation to parliamentary privilege contempt of court defamation or incitement to an offence. (Constitution. 1978, Article -15 of Chapter -3 ). The right to freedom of peaceful assembly may be restricted in the interests of racial and religious harmony', while freedom of association may be restricted in the interests of racial or religious harmony and national economy.

Although Sri Lanka acceded to the International Covenant on civil and political rights (ICCPR) in 1980 and therefore is bound to comply with its provisions.(ICCPR.1980). The restrictions set forth in Article 15(2) of the constitution are far broader than those permitted by the ICCPR, freedom of expression and other fundamental rights may be restricted only 'if necessary' to promote certain enumerated interests. Under the constitution of Sri Lanka, restrictions not only do not need to be necessary, they do not even have to be reasonable. This point was highlighted by the Supreme Court in the case filed by the Attorney General against P. Malalgoda, a radical poet, author, politician in1982. The Supreme Court stated: "In Sri Lanka the operation and exercise of the right to freedom of speech are made subject to restrictions of law not qualified by any test of reasonableness of the law and imposing restrictions is open to question unlike in America or India".(SLR.777)

\section{RESTRICTIONS ON FREEDOM OF MEDIA IN SRI LANKA}

As already stated it is necessary to maintain and preserve media in a democracy. But at the same time it is also necessary to place some restrictions on this freedom for the maintenance of social order, because no freedom can be absolute or completely unrestricted. Accordingly, under Article 15(2) of the Constitution of Sri Lanka.(Constitution. 1978) the Government may make a law imposing reasonable restrictions on the exercise of the right to freedom of media in the interest of the publicon the following: Sovereignty \& Integrity of Sri Lanka, Security of the country, parliamentary privileges, Public Order,Emergency Regulations, Contempt of Court, Defamation, Incitement to an OffenceThe grounds mentioned above reveal that they are all concerned with either the national interest or in the interest of the society.

The first set of grounds, namely, the sovereignty and integrity of Sri Lanka, the security of the country and public order are all grounds referable to national interest. Whereas the second set of grounds, namely, decency or morality, contempt of court, defamation and incitement to an offence are all concerned with the interest of the society. However it is the constitutional obligation of the judiciary to ensure that the restrictions imposed by a law on the media are reasonable and relate to the purposes specified in Article 15(2).Because reasonable restrictions contemplated under the Sri Lankan Constitution brings the matter in the domain of the court as the question of reasonableness is a question primarily for the Court to decide. 


\section{PARLIAMENTARY PRIVILEGES}

The restrictions of freedom of expression in the interests of parliamentary privilege and contempt of court go well beyond the restrictions authorized by the ICCPR. Secondly, the restrictions on freedom of association in the interest of the national economy are also far broaden that the restrictions authorized by the organization. For example, parliamentary privilege allows parliament to punish journalists and editors under the parliamentary powers privileges Act. This Act has substantially broadened the earlier Acts which was passed five years after independence. The parliament powers and privileges act no, 21 Of 1953 was a limited one and under the act, the only offence relating to publication of committee proceedings before they had been reported to the full House. Imprisonment or fine could be imposed only by the Supreme Court after a trial(Constitution. 1953).

The 1978 amendment parliament powers and privileges Amendment Lawno.5 of 1978 authorized the parliament to impose up to two years' imprisonment and fines, and expanded the kinds of publications which it could punish.(Constitution. 1978), Another clause was added to this list by Parliament Act No.17 of 1980, namely "the willful publication of any word or statements after the Speaker has ordered such words or statements to be expunged from the official report of Parliamentary debates"(Constitution. 1980).The most disturbing part of the 1978 law and the subsequent amendment is that it authorizes Parliament to subject people to criminal penalties for matters in the public interest even in the absence of specific rules of procedure and without the advice of the Attorney General. In a country where the Parliament generally is dominated by obsolutemajorities the assumption of such power poses a threat to principles of natural justice. In one of the cases, the Parliament used its powers to severely warn and fine editor Philip Cooray of the state-owned the observer for a minor error of caption which was to be published with a photograph of the then Foreign Minister ShahulHameed. Although it became apparent that it was not done in malice and was only a case of recklessness and negligence, the Parliament decided to warn and fine the editor.

Following this, at the request of the civil rights movement (CRM), a well-known constitutional lawyer, S. Nadesan, Queen's Counsel, made a study of the law of parliamentary privilege, the amending act, and the exercise of judicial power by parliament in the observer case. The report, which was serialized in the independent newspaper, the sun, demonstrated the undesirability of Parliament acting in a judicial power by parliament in the observer case. The report, which was serialized in the independent newspaper, the sun, demonstrated the undesirability of parliament acting in a judiciary capacity and that the observer case must be treated as an unfortunate episode in the history of parliamentary democracy.
As a result of the publication in the sun, Mr.Nadesan was himself charged with breach of privilege, but parliament decided this time to refer the case to the Supreme Court. At the end of the trial, Mr. Nadesan was acquitted and the supreme court in its Judgment said: "It must be born in mind that the view that the power to deal with offences of breach of privilege should be left to the court and not be exercised by parliament has been expressed not only in this country but is one taken by legal experts in almost all parts of the commonwealth."(Supreme.1980).

In 1992, some opposition members demanded that editor H.L.D. Mahindapala and news editor Nicholas candappa of the observer and editor Manic Silva of the daily news (both are state-owned newspaper) be called before the house to be dealt with for breach of privilege. However, no follow up action was taken mainly because of the protest campaign launched by journalists' organizations and the civil rights movement.

The parliamentary privilege law no.5 of 1978 made all offences specified in the schedule of the act punishable by the Supreme Court and the legislature. The main criticism of this was that the Supreme Court or the parliament becomes the judge and the victim at the same time. The parliament brought charges against journalists and editors on certain issues under this act and it was criticized by commentators. However the attorney general has filed a case on one occasion when a leading lawyer had published articles in newspaper criticizing this piece of parliamentary legislation which endows parliament with judicial powers. (Constitution.1978)However, on that occasion, the Supreme Court ruled that parliamentary legislation and proceedings are matters that may be the subject of fair comment.It is a matter of satisfaction that the people's alliance, in its election manifesto released for August 161994 parliamentary elections stated that "Journalists will no longer be punished by committees of parliament".

\section{EMERGENCY REGULATIONS}

Since 1983, SriLanka had been ruled under a declarationof national emergency under the regulations 14, Emergency regulations, No 1 of 1983. The head of government has the authority to declare state of emergency and emergency regulation prevails over all the other laws except the constitution.Article 155(3) of the constitution (Constitution1983). Emergency regulations in the last decade prohibited the affixing of posters or distribution of leaflets without permission of the Inspector General of Police, prohibited public meeting and processions, banned newspaper, sealed printing presses, censored publications and broadcasts and proscribed political parties. Some of these regulations have been changed without any notice.

\section{DEFAMATION}

Under the 1972 Constitution freedom of expression was subject to various other regulations made in the interest of 
efficiency, discipline, health, morality, public order, etc. The way these regulations were used made the commentators say that the law of contempt had been used as a sword and not as a shield. Among the other restrictions on free speech was the regulation on defamation.(Constitution, 1972). The fear of free speech was the regulation on defamation, the fear of free speech is one of the main reasons that the area of defamation is a vibrant and very important area of the law. Defamation has been defined as a restriction on free speech and individual is not free to impugn the reputation or the character of another.

Code Section 479 of the Sri Lankan penal provides that a person is guilty of criminal defamation, and may be punished with up to two years imprisonment and a fine, if he or she publishes an imputation, intended to harm, or knowing or having reason to believe that such imputation will harm the recognized. They include truth for the public good, fair comment and publication of judicial proceedings. public individuals are allowed to prosecute a person for criminal defamation only on approval of the Attorney General.(Constitution.1972.penal Code Law. Section 479)

\section{CONTEMPT OF COURT}

The Supreme Court of Sri Lanka ruled in1983 that publication of a report of a parliamentary proceeding, even though fair, accurate and made without malice, nonetheless may be punished if it constitutes a contempt of court, This ruling was given in the case Hewamanne V. Manick de Silva, editor of the Daily news .The editor and the owner of the newspaper, which is a state-owned newspaper,were found guilty of contempt of court for publishing a news item containing matter defamatory of two Supreme Court Judges, even though the defamatory matter was contained in a document that formed part of the proceedings of the House of parliament. Although they were found guilty, the Court did not impose any punishment.

\section{JUDICIAL TREND}

The government has authority to restrict the access to official secrets and secret documents and to prevent unauthorized disclosure thereof under the official Secrets Act of 1955 . However the definition of official secrets is considerably broader than what the international standards seem to permit.(Constitution,1955).

The Supreme Court has ruled that freedom of publication cannot extent to matters of official secrets and confidentiality, It also stated that the freedom to propagate one's ideas may be restricted in the interest of the national economy And the principles of governmont policy. Article 14(1) of the Constitution of the Democratic Socialist Republic of Sri Lanka Which came into effect on February 4, 1978 says, every citizen is entitled to the Freedom of speech and expression is including publication.However the subsequent clauses clarify that this right may be restricted by law in the interest of national security, racial and religious harmony, or in relation to parliamentary privilege , contempt of court defamation orincitement to an offence, On number of occasions, the supreme Court of Sri Lanka had to interpret these provisions. Some of the interpretations could not be described as favorable to ensure media freedom.

One such interpretation was on the case Neville Fernando and others v Liyanage (Supreme Court Application No.116 of 1981) in which the verdict of the Supreme Court of Sri Lanka was that the media industry, being a corporate body does not enjoy freedom of speech . Their contention was that only individuals enjoy freedom of speech as it is considered to be the center of Information.Hence, it can be argued that freedom of speech and publication enshrined in the Constitution becomes meaningless if the media which is the Centreof informationdid not enjoy this right. The Supreme Court interpretation that the media did not enjoy freedom of Expression was not una1nimous and there was a strong dissenting opinion from the learned Judge, Justice Raja S. Wanasundara (Supreme,1983).

However,the Supreme Court of Sri Lanka has stated that every citizen is entitled to the freedom to receive information from government .This right, which has only been recognized in other jurisdictions only recently, was recognized by the Sri LankanJudiciary body in 1984 on its judgment on case Visvalingam v Liyanage.(SLR,1984).

In its judgment on the case Joseph Perera v Attorney General in 1986, the Supreme Court for the first time in the recent history of Sri Lanka, threw aside an emergency regulation. The judgment stated that prior restraint of publicationswas unconstitutional and such action bears a heavy presumption against its constitutional validity and that emergency regulation which vest police officers with broad discretion to censor without proper guidelines are unconstitutional.(SLR,1992).It was an important and far reaching Judgment.

\section{CONCLUSION AND SUGGESTIONS}

From the above it can be concluded that in a democracy, thegovernment cannot function effectively unless the citizensare well informed and free to participate in public issues byhaving the widest choice of alternative solutions of theproblems that arise. So the fact remains that the media playsan important role in the development and stability of modernsociety, but at the same time the need of the hour is toimpose a commitment of social responsibility on media.As this overview of Sri Lankan media Law show, their social mediaenjoy a wide range of legal rights and privileges enabling them to carry out their essential roles of providing meaningful news and commentary on public affairs. A free, vigorous, and outspoken media is indeed essential to a healthy society. It is important, too that the principals and theory of media are deeply embedded in constitutional law and are not just the yearnings of a handful of radicals and dissidents. All supporters of the Sri Lankan 
Constitution, including the most conservative or reactionary judges should uphold freedom of media when they enforce the law.

There is a mushrooming growth of print and electronic media in Sri Lanka which provides all sort of social and psychological gratification to the audience. However, this proliferation of media is meaningless, particularly, when there is an absence of access to information, and rules and regulations controlling media freedom. Sri Lankan's print and electronic media are not pluralistic as they are mostly restricted to the major cities and prominent people. Mostly media contents are related to politicians, political candidates, Ministers, leading federal and provincial officials, alleged and actual violators., the media has a constitutional duty to considerthe overall needs of society when making journalist indecisions in order to produce the greatest good. Facts mustbe reported accurately and in a meaningful manner.Responsibility, instead of freedom, should be the motto.Such thinking leads to the advocacy of a regulatorymechanism designed to keep the media socially responsible.

The following suggestions are offered in this connection

1. Freedom of media may be inserted as a specific fundamental right in the Constitution of Sri Lanka.

2. The law must strengthen the conditions of freedom of media; protect the right to communicate and the right toinformation. The media cannot perform their role unlessthe law gives them enough power to do so.

3. Freedom of media must, however, be exercised withcircumspection and care must be taken not to trench onthe rights of other citizens or tojeopardizepublicinterest.

It is also the essential duty of media to strike that properbalance between citizen's right to privacy and public's right to information. Let hope for the best from the newly
Sri Lankan peoples party to ensure a realistic freedom of the media in the country.

\section{REFERENCES}

[1] Constitution of the Democratic Socialist Republic of Sri Lankan.(1978). Article -14 of Chapter -3.

[2] Constitution of the Democratic Socialist Republic of Sri Lankan. (1978). Article -15 of Chapter -3.

[3] Constitution of the Democratic Socialist Republic of Sri Lankan (1978). Article -15 of Chapter-2.

[4] Constitution of the Democratic Socialist Republic of Sri Lankan (1953). parliamentary privilege.Act, No 21.

[5] Constitution of the Democratic Socialist Republic of Sri Lankan(1978). parliament privileges. Amendment Law Act.No.5.

[6] Constitution of the Democratic Socialist Republic of Sri Lankan.( 1980). Parliament privileges Act No.17.

[7] Constitution of the Democratic Socialist Republic of Sri Lankan (1978).Parliamentary privilege Law Act.No. 5.

[8] Constitution of the Democratic Socialist Republic of Sri Lankan (1983). Emergency regulations, No 1

[9] Constitution of the Democratic Socialist Republic of Sri Lankan.(1972).

[10] Constitution of the Democratic Socialist Republic of Sri Lankan.(1972).penal Code Law .Section 479.

[11] Constitution of the Democratic Socialist Republic of Sri Lankan.(1955). Act No -32.Section 27.

[12] Daft Committee. (1948). The Universal Declaration of Human Rights, United Nations General Assembly. Palais de Choillot, Paris, France.

[13] International Covenant on Civil and Political Rights.(1980). United Nation Headquarters., New York.

[14] Norris, P.(2006). The Role of the Free press in promoting democratization, good governance and human development.Paper presented at UNESO world press freedom day 2006, Colombo, Sri Lanka. Retrieved from: //portal. UNESCO .org/ci/en/ev.php.url-ID.

[15] Senadhira,S. P., (1996).Under Siege: mass media in Sri Lanka .Segment books. New Delhi, 12.

[16] Sri Lanka Press Council Law.(1973).Act No-5.

[17] Sri Lankan Law Repot.(1989). No. 777.

[18] Sri Lanka Law Repot (1984). 131-132.

[19] Sri Lanka Law Repot. (1992). 199-223.

[20] Supreme court of Sri Lanka. (1980). Appel. No 1.

[21] Supreme Court Application No. 116 of 1981. 